\title{
HAPUSNYA PERIKATAN KREDIT BANK AKIBAT PEMALSUAN TANDA TANGAN OLEH DEBITUR TERHADAP BENDA MILIK ORANG LAIN
}

\author{
I Gusti Ayu Trisna Komala, Fakultas Hukum Universitas Udayana \\ e-mail: tigustiayutrisnakomala@ymail.com \\ Desak Putu Dewi Kasih, Fakultas Hukum Universitas Udayana, \\ email: dewi_kasih@unud.ac.id
}

doi: https://doi.org/10.24843/KS.2020.v08.i11.p11

\begin{abstract}
ABSTRAK
Tujuan penulisan jurnal ini untuk mengetahui konsekuensi yuridis terkait kredit bank yang diperoleh dari tindakan pemalsuan tanda tangan dan mengetahui perlindungan hukum terhadap kreditur atas pelepasan kredit dengan pemalsuan dokumen. Metode penelitian hukum normatif dengan pendekatan perundang-undangan dan konseptual digunakan dalam penulisan artikel ini. Hasil penelitian ini menunjukkan kreditur dan debitur telah melakukan perbuatan melawan hukum dalam pasal 1365 KUHPer karena kreditur lalai dalam kegiatan perbankan dan debitur melakukan penipuan dan pemalsuan dokumen dengan menggadaikan benda milik orang lain sebagai agunan di bank, yang mengakibatkan kerugian terhadap pihak yang bersangkutan yaitu pemegang hak milik benda tersebut. Konsekuensi yuridis terkait kredit bank yang diperoleh dari pemalsuan tanda tangan adalah kredit tersebut batal demi hukum karena tidak memenuhi syarat sahnya suatu perjanjian yang diatur dalam pasal 1320 KUHPer dan pasal 1321 yang menjelaskan tidak ada kesepakatan jika perjanjian terjadi karena adanya kekhilafan dan tipuan. Perlindungan hukum terhadap kreditur karena lalai dalam kegiatan pencairan kredit adalah pihak kreditur terdapat dalam pasal 1265 syarat pengembalian keadaan seperti semula.
\end{abstract}

Kata kunci: Bank, Perjanjian, Kreditur, Peraturan Perundang-Undangan

\begin{abstract}
The aims of study to find out the juridical consequences related to bank credit that obtained from the act of signature forgery and knowing the legal protection of creditors for the release of credit by falsifying documents. The normative legal research method with the legistlavite approach and conceptual approach were used in writing this article. The results of this study are that creditors and debtors have committed acts against the law in article 1365 of the civil code because creditors are negligent in banking activities and debtors commit fraud and falsification of documents by mortgaging other people's property as collateral in the bank, resulting in losses to the parties concerned is that the owner of the propert right. Juridical consequences related to bank credit obtained from falsification of signatures is that the credit is null and void because it does not meet the legal requirements for an agreement provided for in article 1320 of the civil code and article 1321 which explains that there is no agreement if the agreement occurs because of an error and deception. Legal protection for creditors due to negligence in the activities of credit disbursement is the creditor contained in article 1265 conditions of returning the original condition.
\end{abstract}

Keywords: Bank, Agreement, Creditor, Legislation 


\section{Pendahuluan}

\subsection{Latar Belakang Masalah}

Penduduk di Indonesia berjumlah 269,9 juta jiwa yang tercatat pada tahun 2020 dimana terdapat sekitar 8,06 jiwa penduduk Indonesia berpacu pada bidang wirausaha. Hal ini tercatat oleh Kementerian Perindustrian Republik Indonesia. ${ }^{1}$ 8,06 juta jiwa merupakan jumlah yang tidak sedikit. Dimana bentuk usaha yang dilakukan oleh warga Indonesia bervariasi, mulai tergolong dari perusahaan kecil hingga menengah. Masyarakat Indonesia ketika ingin memajukan taraf hidupnya membutuhkan modal untuk berinvestasi, membuat usaha, dan hal-hal yang meningkatkan taraf ekonomi lainnya. Pada umumnya masyarakat yang menjalankan kegiatan usaha membutuhkan permodalan yang tidak sedikit, sehingga kredit bank merupakan salah satu sumber modal yang dapat dimanfaatkan sebagai penambahan maupun pelengkap modal usaha, untuk mendapatkan tambahan dana dapat dilakukan dengan cara mengajukan kredit ke Bank badan usaha yang menyediakan jasa pinjam-meminjam uang. Perbankan membantu pemerintah memajukan kegiatan perekonomian negara. Pasal 1 Ayat (2) Undang-Undang Nomor 10 Tahun 1998 tentang Perbankan (selanjutnya disebut UU Perbankan) menjelaskan pengertian Bank adalah badan usaha yang menghimpun dana dari masyarakat dan dana tersebut disalurkan kembali kepada masyarakat dalam berbagai wujud yang dapat menguntungkan kedua belah pihak. Misalnya, kredit. Kredit merupakan pinjam-meminjam uang atas dasar kesepakatan bersama antara kreditur dan debitur yang mengharuskan debitur menuntaskan seluruh utangnya sesuai dengan kesepakatan waktu dengan tambahan pemberian bunga sesuai kesepakatan perjanjian yang telah ditentukan bersama-sama. ${ }^{2}$ Kredit merupakan kegiatan yang sangat menguntungkan pihak kreditur, yaitu Bank.

Pihak bank dalam melakukan kegiatan pencairan kredit mewajibkan debitur untuk memenuhi syarat-syarat dan prosedur yang diberikan pihak bank. Tidak semua orang bisa mendapatkan pinjaman dari bank. Masyarakat yang ingin mengajukan kredit kepada bank harus memiliki jaminan (agunan) yang dijelaskan dalam UU Perbankan pasal 1 angka 23 yang berupa benda atau harta yang dijadikan sebagai penanggungjawab. Dalam dunia perbankan banyak ditemukan tindakan kecurangan yang dilakukan oleh debitur untuk memperoleh keuntungan pribadi dan merugikan pihak bank maupun pihak lainnya. Kecurangan yang sering terjadi adalah tindakan perizinan pencairan kredit, tindakan ini disebut dengan kredit fiktif. ${ }^{3}$ Dalam kredit terdapat syarat administratif untuk mencairkan kredit dimana syarat tersebut membutuhkan dokumen-dokumen penting dan tanda tangan untuk menyetujui perjanjian kredit. Tanda tangan sangat dibutuhkan dalam hukum pembuktian dalam suatu perjanjian sebagai persyaratan yang harus ada dan digunakan sebagai alat bukti dalam suatu perjanjian, namun terkadang bank kurang berhati-hati dalam

1 Proyeksi Jumlah Penduduk Indonesia 2020, tersedia online di: https://databoks.katadata.co.id/datapublish/2020/01/02/inilah-proyeksi-jumlah-pendudukindonesia-2020 (diakses 02 Januari 2020)

2 Parimandana, I. Wayan Agus Sima, and Ida Bagus Putra Atmadja. "Penyelesaian Kasus Hukum Mengenai Jaminan Fidusia Yang Terkait Kredit Macet Pada CIMB Niaga Auto Finance." Kertha Semaya: Journal Ilmu Hukum, 1, no. 10 (2018): 3-12.

3 Agustini, Ni Luh Wayan Kori, Cok Istri Anom Pemayun, and Dewa Gede Rudy. "Pertanggungjawaban Bank Terhadap Nasabah Yang Identitasnya Dipakai Tanpa Izin Dalam Kredit Fiktif." Dewi Cahyono, A.R.D.Y "Ciri Wanprestasi Dan Tindak Pidana Penggelapan Yang Lahir Dari Hubungan Kontraktual." Jurnal Novum 3, no. 4 (2016):52-60. 
menganalisa nasabahnya sehingga terjadi hal yang tidak diinginkan, seperti penipuan dan pemalsuan dokumen-dokumen penting oleh debitur. Tindak pidana di bidang perbankan adalah jenis perbuatan melanggar hukum yang memiliki kaitan dengan kegiatan-kegiatan dalam menjalankan usaha bank, sehingga menimbulkan perbuatan yang dapat diperlakukan dengan peraturan yang mengatur kegiatan perbankan yang mencantumkan ketentuan pidana secara umum atau khusus, selama hal tersebut belum ada peraturan-peraturan hukum pidana yang dibuat secara khusus untuk menghukum tindakan-tindakan tersebut. Tindak pidana perbankan merupakan tindak pidana yang memenuhi unsur-unsur dalam pasal 46 sampai pasal 50A UU Perbankan atau pasal 59 sampai 66 UU Perbankan Syariah Tindak pidana di Bidang Perbankan dapat dilakukan secara internal yang dilakukan oleh pihak bank dan eksternal yang dilakukan oleh orang luar. 4

Bank dan debitur telah melakukan pelanggaran hukum yaitu perbuatan melawan hukum yang mengakibatkan adanya kerugian terhadap pihak lain ketentuan ini dijelaskan pada pasal 1365 KUHPer. Pihak bank telah lalai dalam melaksanakan tugasnya karena tidak mematuhi prinsip-prinsip kehati-hatian bank dan debitur telah melanggar hukum karena melakukan kecurangan dengan cara memalsukan dan melakukan penipuan dokumen dan tanda tangan. Masalah ini merupakan persoalan perdata yang penyelesaiannya dapat menggunakan jalur pidana. Bank yang telah lalai dalam kegiatan perbankan harus tetap bertanggungjawab atas perbuatan yang telah dilakukannya hal ini dijelaskan dalam pasal 1366 KUHPer tentang kelalaian dalam bertindak. UU Perbankan pada pasal 29 Ayat (4) Bank wajib bertanggungjawab kepada pihak yang dirugikan. Pertanggungjawaban ini dibedakan menjadi 2 yaitu $^{5}$ : tanggungjawab dari pihak bank dan dari pegawai bank. Sedangkan debitur yang melakukan kecurangan dan memalsukan dokumen-dokumen penting beserta tanda tangan melakukan perbuatan melawan hukum yang dijelaskan dalam pasal 1365 KUHPer. Debitur telah melakukan pelanggaran terhadap undang-undang karena melakukan perbuatan melawan hukum dan mengakibatkan adanya kerugian secara materill maupun imateriil terhadap pihak lain. Pemalsuan dokumen diatur dalam pasal 263 ayat (1) KUHP serta penipuan diatur dalam pasal 378 KUHP. Perbuatan pihak bank dan debitur sudah dijelaskan dalam KUHPer dan KUHP maupun UU Perbankan, sanksi dan hukuman yang akan didapatkan oleh pihak-pihak tersebut karena telah melakukan pelanggaran hukum. Oleh karena itu dalam penelitian ini akan membahas secara spesifik tentang konsekuensi yuridis terhadap kredit bank yang diperoleh karena melawan hukum dan perlindungan hukum terhadap kreditur atas pelepasan kredit.

\subsection{Rumusan masalah}

1. Apakah konsekuensi yuridis dari kredit bank yang diperoleh secara melawan hukum melalui pemalsuan tanda tangan yang dilakukan oleh debitur?

2. Bagaimanakah perlindungan hukum terhadap kreditur atas pelepasan kredit dengan pemalsuan dokumen yang dilakukan oleh debitur?

${ }^{4}$ Faridah, Hanna. “Jenis-jenis Tindak Pidana Perbankan dan Perbandingan Undangundang Perbankan." Jurnal Hukum Positum 3, no. 2 (2018): 106-125.

5 Sampul, Marselina. "Tanggung Jawab Bank Terhadap Hak Yang Dirugikan Dalam Pembobolan Rekening Nasabah Menurut Undang-undang Nomor 10 Tahun 1998 Tentang Perbankan." Jurnal Lex Crimen 5, no. 7 (2016): 125-132. 


\subsection{Tujuan Penulisan}

Dengan adanya penulisan karya ilmiah bertujuan untuk mengetahui konsekuensi yuridis terkait kredit bank yang diperoleh dari tindakan pemalsuan tanda tangan dan mengetahui perlindungan hukum bagi pihak bank yang terlanjur mencairkan kredit kepada debitur yang melakukan pemalsuan dokumen.

\section{Metode Penelitian}

Artikel ini dibuat dengan metode hukum normatif yang artinya penelitian dalam artikel ini dilakukan dengan cara mengkaji norma hukum yang mengatur suatu peristiwa hukum, yang berkaitan dengan prinsip hukum untuk menjawab isu-isu hukum yang ada dengan menggunakan Peraturan Perundang-Undangan, Studi Perpustakaan, dan pendapat sarjana hukum. Jenis pendekatan menggunakan pendekatan perundang-undangan (Statue Approach) yaitu Undang-Undang No. 10 Tahun 1998, Undang-Undang No. 21 Tahun 2011, KUHPer, KUHP dan konseptual (Conceptual Approach), yang maksudnya adalah menjawab isu-isu hukum dengan menggunakan peraturan undang-undang yang berlaku.

\section{Hasil dan Pembahasan}

\subsection{Konsekuensi Yuridis Kredit Bank Yang Diperoleh Dari Tindakan Pemalsuan Tanda Tangan}

Hubungan hukum dalam perjanjian kredit terdiri dari kreditur dan debitur yang telah menandatangani perjanjian sebagai subyek hukum dalam perjanjian kredit bank. Dalam pemberian kredit para pihak akan membuat perjanjian yang disebut dengan perjanjian kredit. Dalam KUHPer tidak mengatur secara khusus tentang perjanjian kredit ${ }^{6}$ dan UU Perbankan juga tidak membahas pengertian perjanjian dalam kredit bank.7 R. Subekti berpendapat ${ }^{7}$ " Pemberian kredit itu sama artinya dengan kesepakatan dalam meminjam uang antara debitur dan kreditur yang sudah diatur pada suatu perjanjian yang sah "hal ini berdasarkan pasal 1754-1769 KUHPer tentang perjanjian kredit dan pada BAB III KUHPer mengatur mengenai pinjam meminjam uang. Kegiatan kredit akan dilandasi oleh suatu perjanjian, syarat-syarat sahnya suatu perjanjian diatur dalam pasal 1320 KUHPer yakni: adanya kata sepakat, kecakapan para pihak untuk melakukan suatu perjanjian, adanya suatu hal dan suatu sebab yang halal. Suatu perjanjian kredit bank harus dibuat secara tertulis sesuai pengertian dari Asas kebebasan berkontrak terdapat pada Pasal 1338 ayat (1) KUHPer yang merupakan kesepakatan dan undang-undang untuk mereka dan dibentuk oleh para pihak dengan perjanjian yang sah. Karena perjanjian tersebut mengikat para pihak, yang hanya dapat ditarik maupun diubah berdasarkan kesepekatan bersama. Instrumen pasal 224 HIR/ Pasal 258 R.Bg memberikan syarat pengakuan utang, harus dibuat dengan akta autentik syarat itu bersifat mutlak dan harus dipenuhi, karena syarat tersebut memiliki kekuatan hukum. Apabila syarat-syarat dalam Instrumen Pasal 224HIR/ Pasal 258 R.Bg tidak terlaksana, maka surat pengakuan utang dianggap batal demi hukum. Pembatalan suatu perjanjian kredit dapat disebabkan karena

6 Sutarno. Aspek-aspek Hukum Perkreditan Pada Bank, (Bandung, 2003), 95.

7 Wastu, Ida Bagus Gde Gni, I. Gusti Ngurah Wairocana, and Desak Putu Dewi Kasih. "Kekuatan Hukum Perjanjian Kredit Di Bawah Tangan Pada Bank Perkreditan Rakyat." Acta Comitas: Jurnal Hukum Kenotariatan 2, No. 1 (2017): 83-98.

8 Ps, Bambang Catur. "Pengamanan Pemberian Kredit Bank Dengan Jaminan Hak Guna Bangunan." Jurnal Cita Hukum 2, No. 2 (2014): 273-288. 
berbagai hal, seperti pemalsuan dokumen, pemalsuan tanda tangan dan berbagai hal lainya yang dapat merugikan berbagai pihak.

Pemalsuan dokumen dan tanda tangan sering terjadi dengan cara menjaminkan barang miliki orang lain sebagai jaminan di bank tanpa diketahui pemilik aslinya. Hal ini merupakan perbuatan yang sangat fatal yang dapat menyebabkan terjadinya perbuatan hukum melawan hukum yang masuk dalam perbuatan hukum perdata dan bila ditindak lanjuti ke pengadilan maka akan masuk ke dalam ranah hukum pidana. Kontrak yang sudah disepakati bersama oleh para pihak, jika di dalamnya terdapat unsur perbuatan pemalsuan, penipuan, adanya sebuah kebohongan atau keadaan palsu antara para pihak maka hal tersebut dikategorikan sebagai perbuatan penipuan dalam hukum pidana yang berdasarkan pasal 263 KUHP tentang penipuan dan pasal 378 Ayat (1) tentang pemalsuan. Sedangkan dalam KUHPer perbuatan ini termasuk dalam perbuatan melawan hukum yang diatur dalam pasal 1365 KUHPer menyebutkan "Tiap perbuatan yang melanggar hukum dan membawa kerugian kepada orang lain, mewajibkan orang yang menimbulkan kerugian itu karena kesalahannya untuk menggantikan kerugian tersebut."

Menurut Arrest Cohen- Lindenbaum dapat dikatakan perbuatan melawan hukum jika terjadi: ${ }^{9}$

\section{a. Perbuatan melawan hukum}

Perbuatan melawan hukum disebabkan karena adanya sebuah faktor dari luar (eksternal) maupun dari dalam (internal). ${ }^{10}$ Contohnya seperti melanggar hak subjetif orang lain. Maksudnya adalah seseorang telah melakukan pelanggaran yang bersifat pribadi terhadap hak-hak seseorang yang dilindungi oleh hukum. Seperti hak kebendaan. Selaku dengan pemilik jaminan, bila pihak tersebut tidak pernah melakukan pengajuan kredit dan menjaminkan jaminan hak miliknya kepada pihak bank dan di dalam perjanjian kredit tersebut tidak dibebankan pembuatan akta hak tanggungan dan pembebanan hak tanggungan jatuh kepada dirinya maka hal tersebut batal demi hukum karena tidak mengikuti prosedur hukum yang sah karena pemilik jaminan tidak merasa hadir dan menandatangi akta otentik tersebut. Dalam membuat perjanjian utang, pemilik jaminan tidak merasa pernah ikut dan menyetuji surat perjanjian utang maka hal tersebut bisa batal demi hukum. Berdasarkan pasal 1335 KUHPer yang menjelaskan "Suatu persetujuan tanpa sebab, atau dibuat berdasarkan suatu sebab yang palsu atau yang terlarang, tidaklah mempunyai kekuatan."

\section{b. Terdapat sebuah kesalahan}

Kesalahan dibagi menjadi 2 jenis yaitu terjadi karena adanya ketidak sengajaan dan kesengajaan. Dalam pemalsuan dokumen dan tanda tangan disini kreditur kurang teliti dalam menerapkan prinsip kehati-hatian bank sehingga terjadi kealpaan dalam melakukan pencairan kredit kepada debitur. Sedangkan, debitur dengan sengaja melakukan perbuatan pemalsuan tanda tangan dan dokumen. Bank wajib menerapkan prinsip kehati-hatian bank dalam pemberian kredit, karena dari pemeriksaan

9 Tanaya, Velliana. “Rekontruksi Asas Perbuatan Melawan Hukum (Onrechtmatigedaad) Dalam Gugatan Sengketa Konsumen." Asy-Syir'ah: Jurnal Ilmu Syari'ah dan Hukum 47, no. 1 (2013). 313-314.

10 Weydekamp, Gerry. "Pembatalan Perjanjian Sepihak Sebagai Suatu Perbuatan Melawan Hukum." Lex Privatum 1, No. 4 (2013): 148-158. 
kelengkapan data dan dokumen kreditur dapat menilai karakter calon debitur bank dalam menjalankan kegiatan usahanya harus mematuhi peraturan perundangundangan yang berlaku secara konsisten dengan didasari oleh itikad baik. Prinsip kehati-hati bank dalam pemberian kredit terdiri dari:
a. Prinsip Kepercayaan
b. Prinsip Kehati-hatian
c. Prinsip 5-C (Character, Capacity, Capital, Collateral, Condition of Economic)
d. Prinsip 4-P (Purpose, Payment, Profitabilitas, Protection)
e. Prinsip 3-R (Returns, Repayment, Risk Bearing Ability) ${ }^{11}$

\section{c. Terdapat hubungan yang menyebabkan terjadinya kerugian dari perbuatan}

Kerugian yang terjadi karena pemalsuan dokumen dan tanda tangan menyebabkan kerugian kepada pihak yang tidak ikut serta dalam melaksanakan perjanjian kredit tersebut yaitu pemilik jaminan benda yang dijadikan sebagai agunan di bank. Jika pelaku tidak melakukan tindakan yang melanggar undang-undang dan hak orang lain maka dipastikan tidak akan terjadi perbuatan melawan hukum. Pihak yang dirugikan karena adanya perbuatan kreditur dan debitur dapat menyelesaikan permasalahan ini ke jalur hukum perdata tetapi jika kreditur dan debitur tidak ada itikad baik untuk menyelesaikan masalah melalui jalur perdata dengan pihak yang dirugikan maka penuntutan perdata akan dapat menjadi penuntutan pidana. Hukum pidana merupakan ancaman senjata terakhir bila jalur perdata tidak bisa menyelesaikan masalah tersebut.

\section{d. Terdapat kerugian}

Pasal 1365 KUHPer berisi tentang hubungan antara kerugian dengan perbuatan. Menurut Subekti ganti rugi dibagi menjadi 3 unsur, yaitu : biaya, rugi dan bunga. ${ }^{12}$ Ketika bank alpa dalam melakukan pencairan kredit dan debitur melakukan pemalsuan tanda tangan maupun dokumen terhadap kepemilikan barang milik orang lain, maka kreditur dan debitur tersebut harus ganti rugi karena telah melakukan perbuatan hukum. Terdapat 2 bentuk ganti rugi, yaitu secara materiil dan secara imateriil. Ganti rugi materiil berupa remunerasi dengan sejumlah kerugian yang telah dialami korban dan ganti rugi materil adalah ganti rugi yang dialami oleh korban berupa penderitaan, trauma, dan yang berkaitan dengan mental seseorang yang berdampak pada tingkah laku,dan pola pikir seseorang. ${ }^{13}$ Dalam melakukan pemalsuan dokumen pihak yang dirugikan dapat mengajukan gugatan pidana maupun perdata. Keduanya dapat berjalan secara bersamaan.

Dalam melaksanakan perjanjian maka hal itu harus diawali oleh perikatan yang diatur dalam pasal 1313 KUHPer yang menjelaskan perikatan harus dilakukan lebih dari satu orang yang mengikatkan diri satu sama lain. Dalam perjanjian kredit ini pihak yang memiliki jaminan tidak ikut serta dalam perjanjian kredit sehingga

11 Handayani, Pristika. "Prinsip Kehati-Hatian Bank Dalam Pemberian Kredit Ditinjau Dari Undang-Undang No. 10 Tahun 1998 Tentang Perbankan." Jurnal Dimensi 4, No. 2 (2016). 112.

12 Maysarah, Andi. “Mekanisme Ganti Kerugian terhadap Korban Tindak Pidana." Warta Dharmawangsa 59 (2019): 59- 103.

${ }^{13}$ Winastri, Rivo Krisna, Ery Agus Priyono, and Dewi Hendrawati. "Tinjauan Normatif Terhadap Ganti Rugi Dalam Perkara Perbuatan Melawan Hukum Yang Menimbulkan Kerugian Immateriil (Studi Kasus Putusan Pengadilan Negeri Istimewa Jakarta No. 568/1968. g)." Diponegoro Law Journal 6, No. 2 (2017): 1-18. 
konsekuensi yuridis kredit bank yang diperoleh dari tindakan pemalsuan tanda tangan secara hukum dapat dikatakan batal demi hukum. Jika terjadi suatu kecurangan atau pemalsuan dokumen yang dilakukan debitur terhadap kredit yang sudah dicairkan kreditur maka kreditur dapat membatalkan perjanjian kredit sesuai dengan penjelasan pada pasal 1328 KUHper yang merupakan dua koridor hukum yang dapat ditempuh seseorang jika merasa mengalami kerugian terhadap adanya hubungan kontrak tersebut, yang diketahui jika adanya tipu palsu, kata bohong maupun keadaan palsu. Selain itu faktor pendukung perjanjian dapat dibatalkan adalah syarat sahnya suatu perjanjian dalam pasal 1320 KUHPer tidak terpenuhi karena tidak ada kata sepakat dari pemilik jaminan dan adanya perbuatan terlarang dengan melakukan pelanggaran hukum dan pasal 1321 KUHPer menjelaskan tidak ada persetujuan yang memiliki kekuatan hukum jika di dalamnya terdapat kekhilafan atau yang diperoleh dengan cara paksa maupun penipuan.

\subsection{Perlindungan Hukum Terhadap Kreditur Atas Pelepasan Kredit Dengan Pemalsuan Dokumen.}

Perlindungan Hukum menurut CST Kansil adalah upaya yang dijalankan oleh aparat penegak hukum agar masyarakat tetap merasa aman, terlindungi dari ancaman dari pihak lain. ${ }^{14}$ Kreditur dalam memberikan kredit kepada nasabah harus memperhatikan dengan teliti dan cermat mengenai jenis, harga dari jaminan itu sendiri, status kepemilikan atas jaminan tersebut terutama benda tidak bergerak seperti atas tanah dan bangunan. Irham Fahmi dalam buku yang bertajuk Manajemen Perkreditan, unsur-unsur kredit dibagi menjadi 6 yakni: kepercayaan, tenggang waktu, degree of risk, prestasi, adanya debitur dan kreditur. ${ }^{15}$ Pada dasarnya bank berani memberikan kredit kepada nasabah dengan memiliki keyakinan bahwa kredit yang telah dicairkan dapat dikembalikan dan tidak merugikan. Untuk memperkecil hal-hak yang tidak diinginkan terjadi dikemudian hari akan terjadinya, maka untuk untuk mengurangi resiko yang tidak diinginkan dibutuhkan analisa yang cermat terhadap setiap permohonan kredit Untuk itu bank wajib melakukan evaluasi kepada calon debitur dengan menerapkan prinsip-prinsip analisis kredit perbankan The Five C's of Credit, yakni ${ }^{16}$ :

a. Character merupakan bank harus mengamati keadaan keluarga, kekebiasaan, dan sifat calon debitur.

b. Capacity merupakan kemampuan debitur untuk membayar kembali utangutangnya.

c. Capital merupakan penilaian modal.

d. Condition merupakan keadaan ekonomi dan keadaan pasar ketika melakukan evaluasi.

e. Collateral merupakan jaminan jaminan utama dalam memberikan kredit. Adanya collateral ini karena bank harus sangat berhati-hati dan cermat dan untuk

14 Umardani, Mohammad Kharis, and Lusy Liany. "Penyuluhan Perlindungan Hukum Guru Dan Adab Siswa Sebagai Peserta Didik Tingkat Sekolah Menengah Atas (SMA)." Jurnal Balireso: Jurnal Pengabdian pada Masyarakat 2, No. 2 (2017): 115-130.

15 Widayati, Ratna, and Misa N. Andani. 2019 "Pelaksanaan Prinsip Kehati-Hatian Dalam

Pemberian Kredit Konsumtif Pada Bank Nagari Cabang Siteba." OSF Preprints. Febuary 28.doi:10.31219/osf.io/fgc4r. h. 3-11.

16 Marpaung, Leden. Pemberantasan Dan Pencegahan Tindak Pidana Terhadap Perbankan. (Djambatan, 2003), 71. 
mencegah terjadinya resiko maka bank memerlukan jaminan/ agunan sebagai kompensasi resiko.

Ketentuan Pasal 29 Ayat (2) UU Perbankan menjelaskan prinsip kehati-hatian adalah hal yang harus dan wajib diterapkan dalam dunia perbankan. Bank memberikan pengawasan terhadap adanya perjanjian kredit yang akan diberikan kepada calon debitur, maka 2 bentuk pengawasan, menurut Irham Fahmi, yakni : ${ }^{17}$

a. Model Preventif Control merupakan pengawasan yang dilakukan pihak bank sebelum kredit kepada calon debitur dicarikan.

b. Pengawasan dengan model represif control. Pengawasan ini dilakukan setelah dicairkannya kredit kepada debitur. Agar debitur dapat tepat waktu dan displin dalam melakukan pembayaran dan melunasi pinjamnnya.

Bank wajib menggunakan prinsip mengenal nasabah agar bank dapat mengetahui krakterisitik dari calon nasabah agar tidak terjadi kecurangan seperti pemalsuan dokumen-dokumen penting, pemalsuan tanda tangan untuk mendapatkan pencairan kredit dengan menjaminkan benda hak milik orang lain sebagai agunan kredit di bank. ${ }^{18}$ Kealfaan pihak bank dalam mencairkan kredit kepada debitur dan menimbulkan kerugian terhadap pihak lain maka subyek yang akan bertanggungjawab dalam pelanggaran prinsip kehati-hatian bank adalah organ pengurus atau dewan direksi, dan pegawai bank yang melakukan tanggungjawab terhadap pencairan kredit tersebut. ${ }^{19}$ Perbuatan melawan hukum dapat dilanjutkan ketahap hukuman pidana bilamana terjadi kerugian terhadap pihak yang dirugikan dan penyelesaiannya tidak dapat ditempuh melalui hukum perdata. Dalam membatalkan sebuah perjanjian kredit akibat adanya sebuah pemalsuan dan penipuan yang dilakukan oleh debitur, pihak bank dapat memohon permintaan pembatalan perjanjian kredit di pengadilan melalui hakim hal ini diatur dalam pasal 1266 KUHPer. Dalam pasal 1265 KUHPer menyebutkan syarat batal merupakan syarat yang akan menghapuskan perikatan dan membawa keadaan kembali seperti semula, dan tidak pernah terjadi suatu perikatan. Syarat ini maksudnya kreditur dan debitur hanya mengembalikan apa yang telah diterimanya. Jika terjadi pembatalan perjanjian secara sepihak tindakan ini merupakan tindakan pelanggaran terhadap undang-undang. Permohonan pembatalan perjanjian dapat dilakukan dengan:

A. Melakukan penuntutan aktif di Pengadilan, penututan atas kasus perbuatan melawan hukum di pengadilan negeri melalui tiga tahap peradilan yakni: Pengadilan Negeri, Pengadilan Tinggi dan MA.

B. Menunggu pihak debitur yang beritikad tidak baik untuk melakukan penuntut balik, karena dengan itu ia dapat mengajukan pembelaan. Hakim hanya menerima penuntutan pembatalan jika para pihak mengajukan penuntutan di muka hakim. Jika debitur tidak mau melakukan pengembalian kredit dan berusaha dalam memperlambat pengembalian kredtur maka hal yang diterimanya adalah upaya hukum biasa atau upaya

17 Maryadi, Maryadi. "Pengaruh Pengendalian Kredit Terhadap Kesehatan Bank pada PT. Bank Bukopin Tbk Cabang Cendrawasih Kota Makassar." Jurnal Ilmiah Ilmu Administrasi Publik 7, no. 2 (2017): 81-90.

18 Wowor, Glen. "Kajian Yuridis Tentang Perjanjian Baku Antara Kreditur dan Debitur Menurut Undang-Undang Nomor 8 Tahun 1999 Tentang Perlindungan Konsumen." Lex Privatum 4, no. 1 (2016). 41-50.

${ }^{19}$ Abubakar, Lastuti, and Tri Handayani. “Telaah Yuridis Terhadap Implementasi Prinsip Kehati-hatian Bank Dalam Aktivitas Perbankan Indonesia." DE LEGA LATA: Jurnal Ilmu Hukum 2, no. 1 (2017): 68-91. 
hukum luar biasa. Jika terjadi pembatalan perjanjian secara sepihak tanpa adanya alasan yang sah menurut hukum maka hakim akan melakukan pertimbangan dengan melihat keadaan penggugat dan tergugat hal ini tercantum dalam pasal 1266 KUHPer. Jika debitur tidak mau melakukan pengembalian kredit dan berusaha dalam memperlambat pengembalian kredtur maka hal yang diterimanya adalah upaya hukum biasa atau upaya hukum luar biasa.

\section{Kesimpulan}

Para pihak yang terlibat sebagai subyek dalam perjanjian kredit bank, yaitu kreditur dan debitur melakukan perbuatan melawan hukum hal ini dijelaskan dalam pasal 1365 KUHPer hal ini disebabkan kreditur alfa dalam melakukan kegiatan kredit bank dan pihak debitur melakukan penipuan dan pemalsuan tanda tangan. Perjanjian kredit tidak memenuhi syarat sahnya perjanjian yang diatur dalam pasal 1320 KUHPer karena melakukan pelanggaran hukum dan pihak pemilik agunan tidak menyetujui adanya suatu perjanjian kredit, maka dari itu perjanjian kredit dapat dikatakan batal demi hukum atau dianggap tidak ada karena tidak memenuhi syarat sahnya suatu perjanjian. Perlindungan kreditur yang lalai dalam kegiatan tugasnya maka kreditur dapat mengajukan pembatalan perjanjian secara aktif ke pengadilan karena dengan itu jika pembatalan perjanjian dapat diterima oleh hakim maka sesuai ketentuan pasal 1265 KUHPer membawa keadaan kembali seperti semula, dan tidak pernah terjadi suatu perikatan.

Bank sebaiknya berhat-hati dalam mencairkan pinjaman kredit kepada calon debitur dan sebaiknya melakukan penelitian dengan cermat serta menerapkan prinsip kehati-hati bank dengan teliti dan baik agar tidak terjadi keteldoran dalam melakukan kegiatan kredit. Karena keteledoran yang dilakukan bank sangat merugikan pihak lain yang tidak mendapatkan keuntungan dan mengakibatkan adanya kerugian. Pihak debitur yang melakukan penipuan dan pemalsuan dokumen-dokumen serta tanda tangan dan menggadaikan sertifikat milik orang lain sebagai jaminan di bank, sebaiknya memberikan itikad baik kepada pihak yang dirugikan dengan cara memberikan ganti rugi secara material maupun imateril.

\section{Daftar Pustaka}

\section{$\underline{\text { Buku }}$}

Marpaung, Leden. Pemberantasan dan pencegahan tindak pidana terhadap perbankan. (Djambatan, 2003).

Sutarno, Aspek-aspek Hukum Perkreditan Pada Bank, (Bandung, 2003).

\section{Jurnal}

Abubakar, Lastuti, and Tri Handayani. "Telaah Yuridis Terhadap Implementasi Prinsip kehati-hatian bank dalam aktivitas perbankan Indonesia." DE LEGA LATA: Jurnal Ilmu Hukum 2, no. 1 (2017): 68-91.

Agustini, Ni Luh Wayan Kori, Cok Istri Anom Pemayun, and Dewa Gede Rudy. "Pertanggungjawaban Bank Terhadap Nasabah Yang Identitasnya Dipakai Tanpa Izin Dalam Kredit Fiktif." Dewi Cahyono, A.R.D.Y "Ciri Wanprestasi Dan Tindak Pidana Penggelapan Yang Lahir Dari Hubungan Kontraktual." Jurnal Novum 3, no. 4 (2016):52-60. 
Faridah, Hanna. "Jenis-jenis Tindak Pidana Perbankan dan Perbandingan Undangundang Perbankan." Jurnal Hukum Positum 3, no. 2 (2018): 106-125.

Handayani, Pristika. "Prinsip Kehati-Hatian Bank Dalam Pemberian Kredit Ditinjau

Dari Undang-Undang No. 10 Tahun 1998 Tentang Perbankan." Jurnal Dimensi 4, no. 2 (2016). 1-12.

Maryadi, Maryadi. "Pengaruh Pengendalian Kredit Terhadap Kesehatan Bank pada

PT. Bank Bukopin Tbk Cabang Cendrawasih Kota Makassar." Jurnal Ilmiah

Ilmu Administrasi Publik 7, no. 2 (2017): 81-90.

Maysarah, Andi. "Mekanisme Ganti Kerugian terhadap Korban Tindak Pidana." Warta Dharmawangsa 59 (2019): 59- 103.

Parimandana, I. Wayan Agus Sima, and Ida Bagus Putra Atmadja. "Penyelesaian Kasus Hukum Mengenai Jaminan Fidusia Yang Terkait Kredit Macet Pada CIMB Niaga Auto Finance." Kertha Semaya: Journal Ilmu Hukum. 1, no. 10 (2018): 3-12.

Ps, Bambang Catur. "Pengamanan pemberian kredit bank dengan jaminan hak guna bangunan." Jurnal Cita Hukum 2, no. 2 (2014) : 273-288.

Sampul, Marselina. “Tanggung Jawab Bank Terhadap Hak Yang Dirugikan Dalam Pembobolan Rekening Nasabah Menurut Undang-undang Nomor 10 Tahun 1998 Tentang Perbankan." Jurnal Lex Crimen 5, no. 7 (2016): 125-132.

Tanaya, Velliana. "Rekontruksi Asas Perbuatan Melawan Hukum (Onrechtmatigedaad) Dalam Gugatan Sengketa Konsumen." Asy-Syir'ah: Jurnal Ilmu Syari'ah Hukum 47, no. 1 (2013): 313-314

Umardani, Mohammad Kharis, and Lusy Liany. "Penyuluhan Perlindungan Hukum Guru Dan Adab Siswa Sebagai Peserta Didik Tingkat Sekolah Menengah Atas (SMA)." Jurnal Balireso: Jurnal Pengabdian pada Masyarakat 2, no. 2 (2017): 115130.

Wastu, Ida Bagus Gde Gni, I. Gusti Ngurah Wairocana, and Desak Putu Dewi Kasih. "Kekuatan Hukum Perjanjian Kredit Di Bawah Tangan Pada Bank Perkreditan Rakyat." Acta Comitas: Jurnal Hukum Kenotariatan 2, no. 1 (2017): 83-98.

Weydekamp, Gerry. "Pembatalan Perjanjian Sepihak Sebagai Suatu Perbuatan Melawan Hukum." Lex Privatum 1, no. 4 (2013): 148-158.

Widayati, Ratna, and Misa N. Andani. 2019 "Pelaksanaan Prinsip Kehati-Hatian Dalam Pemberian Kredit Konsumtif Pada Bank Nagari Cabang Siteba." OSF Preprints. Febuary 28.doi:10.31219/osf.io/fgc4r. h. 3-11.

Winastri, Rivo Krisna, Ery Agus Priyono, and Dewi Hendrawati. “Tinjauan Normatif Terhadap Ganti Rugi Dalam Perkara Perbuatan Melawan Hukum Yang Menimbulkan Kerugian Immateriil (Studi Kasus Putusan Pengadilan Negeri Istimewa Jakarta No. 568/1968. g)." Diponegoro Law Journal 6, no. 2 (2017): 1-18.

Wowor, Glen. "Kajian Yuridis Tentang Perjanjian Baku Antara Kreditur dan Debitur Menurut Undang-Undang Nomor 8 Tahun 1999 Tentang Perlindungan Konsumen." Lex Privatum 4, no. 1 (2016). 41-50.

\section{Peraturan Undang-Undang}

Kitab Udang-Undang Hukum Perdata

Kitab Udang-Undang Hukum Pidana

Undang-Undang Nomor 10 Tahun 1998 tentang Perubahan Atas Undang-Undang Nomor 7 Tahun 1992 Tentang Perbankan (Lembaran Negara Tahun 1968 Nomor 1992 Nomor 31, Tambahan Lembaran Negara Nomor 3472). 


\section{Website}

Proyeksi Jumlah Penduduk Indonesia 2020, tersedia online di: https:// databoks.katadata.co.id/datapublish/2020/01/02/inilah-proyeksijumlah-penduduk-indonesia-2020 (diakses 02 Januari 2020 ) 